\title{
From AltNEULAND to NEULAND. RE-INTERPRETATION OF JEWISH/ISRAELI IDENTITY in Modern Hebrew Literature
}

\author{
Daria Boniecka-Stępień \\ https://orcid.org/0000-0003-0204-8422 \\ (Jagiellonian University, Krakow) \\ e-mail: daria.boniecka-stepien@uj.edu.pl
}

Keywords: Israeli literature, Theodor Herzl, Eshkol Nevo, Israel, modern Israeli identity

\begin{abstract}
In 1902, Theodor Herzl, a prominent Jewish thinker and founder of political Zionism, published a utopian novel entitled Altneuland, in which he envisioned, based on ideas of egalitarianism, modern Jewish society in Palestine. In 2011, more than a hundred years after the utopia of Herzl was published, the contemporary Israeli writer Eshkol Nevo, in a way referring to the book of the Zionist ideologist, wrote a moving Israeli family saga entitled Neuland. Since the establishment of the State of Israel, Israeli literature has developed, expressing the experiences and expectations of the young society. Modern Israeli literature developed from realism and a strong Zionist character, through revaluation of the Zionist myth up to the representatives of postmodernism focusing on the personal experiences of the protagonists, detached from the socio-political reality. Modern Israeli literature and in particular Eshkol Nevo's novel, propose new approaches to literature in general and to Jewish and Israeli identity in particular.
\end{abstract}

Contemporary Israeli identity is a matter of interest for researchers from different fields, starting from social studies through culture studies and ending with literature studies. The question of Israeli identity is a complex issue that needs to be investigated from different points of view. One of the main components of modern Israeli identity was, or to be more specific still is, Zionist ideology. It is obvious that Israeli identity is determined by other elements which formed Jewish identity before the creation of the new Jewish state, such as Jewish religion, Judaism, Jewish history, Jewish languages, and the Holocaust. In my article I would like to discuss the correlation between a Zionist novel by Theodor Herzl and a novel by contemporary Israeli writer Eshkol Nevo in the context of Jewish/Israeli identity in modern Hebrew literature.

The Zionist thought of Jewish thinkers of the turn of the 19th and 20th centuries was diverse and diversified. We can recall a few different aspects of Zionist thought, such as spiritual Zionism, political Zionism, socialistic Zionism or even religious Zionism. Jewish thinkers in various parts of Europe discussed and argued about the modern, secular shape of Jewish identity in the pages of Jewish literary and ideological periodicals written in different languages. The process of formulating Zionist ideology was complex and 
it also influenced the process of creating the figure of a new secular Jew, and the figure of the Sabra in Israeli culture.

One of the leaders of the Zionist movement, and its main thinker, the founder of political Zionism and the most well-known figure of Zionism ideology was Theodor Herzl. Herzl was born in 1860 in Pesht, Hungary and died in 1904. His work Der Judenstaat (The Jewish State) published in 1896 in Lipsk is a fundamental text of Zionist thought, but as a journalist, playwright and writer, Herzl also authored many other significant texts. One of them, the Zionist novel Altneuland (Old New Land) published in 1902, is Herzl's vision for a Jewish state in the land of Israel. The novel depicts his Zionist vision of the realization of Jewish national emancipation he had described earlier in Der Judenstaat.

As a representative of Western European enlightened Jewish society, Herzl created his vision of Altneuland based on his Eurocentric point of view. The novel presents a society which was to adopt a liberal and egalitarian social model, resembling a modern welfare state.

Through his Eurocentric prism, Herzl created a vision of a modern Jewish community in the Land of Israel. According to Herzl's vision the answer to the crisis of Jewish identity is a new identity related to Place. This place, which is both new and old at the same time, is the central element of the new Jewish identity, a new identity which had to be, according to Zionist ideology, a compilation of old/new Jew, on the one hand attached to the Jewish tradition, and on the other adopting the ideas of modernity. The Place - The Land of Israel-Palestine - embodies and at the same time legitimizes Jewish existence.

In 2011, over a hundred years after the publication of Herzl's utopian novel, contemporary Israeli writer Eshkol Nevo, with his novel Neuland, started a dialog with the idealistic vision of the most significant Zionist thinker described in The Jewish State and in Altneuland. Eshkol Nevo was born in 1971 in Israel and is a grandson of Levi Eshkol, the late third Prime Minister of Israel. He started publishing at the beginning of the $21 \mathrm{st}$ century. His best-known works are Homesick (2004), World Cup Wishes (2007), Neuland (2011), and Three Floors (2013).

Neuland is on the one hand a great multidimensional and multithreaded family story woven into the history of modern Israel, and on the other a complex approach to the Israeli condition and a discussion on contemporary Israeli identity. Neuland is a journey beyond the literary boundaries of Israel, and Zionism. The title refers to the work of Theodor Herzl, and the book is influenced by a great number of intertexts from modern Hebrew literature. In this great novel Nevo refers not only to Herzl's Altneuland, but also to works of Yehuda Amichai, Orit Gidli, Tamar Karol and others.

As a contemporary Israeli writer, Eshkol Nevo seems to represent a new period in Hebrew literature. In my opinion Nevo's literature is different from literature of other writers of the late 20th century, and in support of this I would like to take a brief look at the history of modern Hebrew literature.

The beginnings of modern Hebrew literature date back to the 18th century and are inseparable from the revival of the Hebrew language as a literary and narrative language. In the pre-state period, the main determinant of Hebrew literature was the Hebrew language - and not the place in which this literature was created. An obvious change 
follows the creation of the State of Israel. Several periods of modern Hebrew literature are distinguished: the Haskala period; tchija - the revival of modern Hebrew literature; and from 1948 on - the periods of Israeli literature written by Israeli writers in the State of Israel. The work of Hebrew literature historians specifies the different generations of Israeli writers and Israeli literature.

The first generation of Israeli writers is known as the 1948 Generation, Ha-Palmach Generation, or Dor ba-arec Generation. Works of this initial period appeared in the late 1940s and 1950s. This generation was born in the 1920s and grew up in the time of the British mandate in Palestine. The writers of this generation focused on the issues of the "Israeli situation" and therefore preferred the realistic style. ${ }^{1}$ Their works reflected the Israeli reality, which was connected with the Zionist ideology and the Israeli War of Independence in 1948. The main themes discussed in the literature of that period were military experiences, Jewish settlement in Palestine, the figure of the new Jew, and the realities of life in new environment. In this period Israelis are depicted as a group, not as individuals.

In the 1960s a new period of Israeli literature dawned. Hebrew literary critics Dan Miron and Gabriel Moked called this new generation of writers Dor ha-medina (the State Generation), and other critics like Aharon Megged or Gershon Shaked referred to it as "The New Wave." These were the writers whose works fall to the beginning of the existence of the State of Israel. Under the influence of the existentialist philosophy flourishing in Western Europe, the State Generation (dor ha-medina) focused on existential issues, the subjects of the "human condition," which were less realistic. ${ }^{2}$ In the literature of this period, anti-heroes come to the fore for the first time. The writers of the State Generation differ from each other; however, the literature itself becomes more problematic, ironic and unrealistic.

During the 1970s and 1980s, Israeli literature became more diverse, and this period is sometimes described in the literature as postmodernism or post-Zionism. It is literature that, above all, takes up the topic of the individual and not, as it was in the previous period, of the whole group. This generation was called ha-gal ha-mefukach, the Sober Generation, because of the disillusionment experienced by these artists, a disillusionment resulting from the Yom Kippur War, and expressed in their work. After this war and its influence, the writers of this generation returned to the subjects of the "Israeli situation." ${ }^{3}$ However, the war led to additional changes in Israeli literature: the character of "Israeli" replaced the character of "Sabra."

Another group of writers from this postmodernist trend is a generation which Professor Avraham Balaban called Ha-gal ha-acher, another wave or a new voice. They are writers of the late 1980s and 1990s who completely abandoned the subject of social experiences. While the writers of Sober Generation are characterized by criticism of the Zionist ideology, this group is characterized by indifference to the social context. The tendency to disengage from the issues of the "Israeli situation" and to turn back to the "human condition" became stronger. Indeed, the works of these writers reflect the

\footnotetext{
1 Oren 2009.

2 Ibid.

3 Ibid.
} 
changes in lifestyle and values that have become accepted in Israeli society: hedonism, escapism, defeatism, and post-Zionism. ${ }^{4}$

Can the writers of the 2000 generation be included in the ha-gal ha-acher generation? It seems obvious that Israeli authors publishing in the 2000s are a different generation. According to researcher and literary critic Josef Oren the writers of the early 21 st century are willing to deal again with the issues of the "Israeli situation," but by means of extreme and imaginary description, usually violent and catastrophic. There appears to be a tendency to produce utopian and dystopian works in their writing. ${ }^{5}$

Now let us ask, where are Eshol Nevo and his work situated? In Neuland Nevo is no longer looking for a personal and subjective approach to refer to contemporary Israeli reality and to Israeli identity. He is engaging in a dialogue with the Israeli and Jewish past rather than searching for new ways of identification - he expresses this by alluding to classical Zionist text. By relating not only to Herzl's novel but also to Jewish and Israeli history, identity, national traumas and problems, Nevo marks a new direction in the literature of his generation.

By telling the story of two Israeli families, the author tells the story of all Israel. He shows the complexity of Jewish and Israeli fate by combining the Jewish past and the Israeli present. Constant interweaving of the past and present allows a dialogue to start between them. By building similarities and correlations Nevo portrays the complexity and, at the same time, continuity and indissolubility of the Jewish history. He shows that the Jewish past is still present in contemporary Israeli life. He is not trying to escape or even to change the history, the past, the experience of the past generations. He faces them and starts a dialogue with them, uses all those experiences to understand complicated and complex Israeli identity. For example, the main character's expedition to South America in order to find his missing father is an obvious correlation to the Israeli trend of traveling to South American countries after completing military service. The hero's destination, however, is completely different. In addition, during the journey he discovers a South American Jewish Zionist episode - the idea of Baron Hirsh to create a Jewish agricultural settlement in 19th century Argentina. Besides that, there are many more references to the utopian vision of Herzl and the text of Altneuland in Eshkol Nevo's novel.

Both novels are built on the same motifs, such as the topos of journey, which relates with searching for a new, better future, and the essence of the journey takes place between different planes, between here and there, between there and here. The motif of the journey, which strongly correlates with the myth of the Eternal Jew recalled by Eshkol Nevo, is for the heroes of both novels a life change, a verification of life plans and expectations. The destination of the journey, a new place, under the influence of travelling experiences turns to be different from earlier expectations. In addition, the heroes are marked by failures and their traumatic pasts.

In my view the most significant relation between the ideological text of Herzl and the story of Nevo is their approach to the land, the place, ha-makom in Hebrew. Relation with the land in Jewish religious tradition is one of the elements of Jewish identity. The land of Herzl is the old/new one (Altneuland). According to Yigal Schwartz, professor of Hebrew literature: "Herzl expressed the tension between the place and the Place, on

\footnotetext{
4 Ibid.

5 Ibid.
} 
Altneuland's topographic plane [...] as the tension between the 'background map' and the 'foreground map' [...] he relied on [...] Haskalah and colonialist sources on the one hand, and romantic, antisemitic sources on the other." ${ }^{6}$ Schwartz understands Altneuland constructed as a story with two spaces - one in the background and the other in the foreground. He claims the background as a narrative past, which reflects the worldview of Herzl's contemporaries. This past takes place in Vienna in 1902, Herzl's own home and his reference point. In contrast, the foreground of the utopian story shows the future life in Eretz Israel twenty years later, in 1923. This historical future is shown as a narrative present, which reflects Herzl's new landscape conceptualization.

Both Herzl's Altneuland and Nevo's Neuland refer in a special way to the land, to the place, to Eretz Israel. Nevo, however, changes the historical planes proposed by Herzl. Herzl's background story is related to the present, which determines dissatisfaction and trauma. Nevo does something similar, but the difference is the place that triggers these traumas. In Altneuland it is an old place, Europe, but in Neuland it is the new place, which is Israel itself. The transition to the foreground, to this utopian space helps us to face the past, helps us to look at it from a different perspective. While Herzl's text is mainly utopian and didactic, Nevo's novel shows the problem that the author wanted to point out. Namely, it is the inability to deal with his own Israeli identity from the perspective of the place itself, from the perspective of Israel. It turns out that the different journeys of the heroes of Nevo's novel are to help them face their own condition. Only by changing the place where they used to live, does it become possible for them to understand their multidimensional identity, to realize and to try to solve their difficulties and problems, to tame their traumas.

Esti Adivi-Shoshan presents a different perspective on story planes, claiming that Nevo's novel is constructed on two levels. She reads Neuland and Nevo's earlier book Homesick from the perspective of an open, visible plane and from that of an unseen, hidden plane. What is very interesting, according to her, is that the visible plane reflects a certain type of contemporary Israeliness, while that plane which is unseen deals with deep traumas of Israeli society. ${ }^{7}$

Moreover, at the end of the story, Nevo makes another unexpected change in the heroes' current perspective. The heroes who travelled between the planes, where the utopian foreground became their present, are brutally uprooted from their unrealistic journey by the outbreak of war in Israel in 2006, the Second Lebanon War. The war turns their perspectives upside-down, making them realize that what they really understood as their background and their life in Israel is their reality and the foreground.

Eshkol Nevo's novel, while referring to the utopian novel by Theodor Herzl from the beginning of the 20th century, attempts to verify his vision and ideas. At the same time, Nevo multidimensionally describes Israeli modernity. Neuland shows the complexity of the Israeli identity expressed in complicated family lives and relations and their rich history. This identity consists also of Israeli traumas like the Holocaust, the Israeli-Arab wars and military conflicts, post-traumatic stress, and suicides, but also of personal traumas as complicated, difficult interpersonal relations between partners, parents and children. One can read Neuland in many ways, including political, but one thing is certain:

${ }^{6}$ Schwartz 2014a: 52.

${ }^{7}$ Adivi-Shoshan 2013: 317. 
in creating this image of the contemporary Israeli society, Nevo undertook a difficult process of looking at his identity and the identity of his compatriots from a more distant perspective.

Finally, I would like to point out that the current approach to Israeli literature from the internal, or Israeli perspective, is beginning to change. Until now, Israel itself has been the main element determining the literature, and its heroes.

Currently, researchers such as the aforementioned Yigal Schwartz note that one should try to interpret and describe Israeli literature as a relation between Israel and other places. ${ }^{8}$ Contemporary Israeli literature is a phenomenon that is still unfolding, which is why so much interesting research is still ahead.

\section{BIBLIOGRAPHY}

\section{Sources}

Herzl, T. (1902), Altneuland, Hofenberg.

Herzl, T. (1896), The Jewish State, Austria.

Nevo, E. (2011), Neuland, Jerusalem.

\section{Literature}

Adivi-Shoshan, E. (2013), Olam hadash ve-tov ani 'eten leha: Al ha-sefer Neuland me-'et Eshkol Nevo [I will give you a new and good world: About Neuland by Eshkol Nevo], Ha-Hinuh ve-svivo, vol. 35: 317-326.

Oren, Y., (2009), Kitzur toldot ha-sifrut ha-israelit [A short history of Israeli].

Schwartz, Y. (2014a), The Zionist Paradox. Hebrew Literature and Israeli Identity, Waltham, Massachusetts.

Schwartz, Y. (2014b), Ha-Ashkenazim. Ha-merkaz neged ha-mizrah (The Ashkenazim. Center against the East), Bar Ilan.

\section{Internet sources}

Literature, Ma'amakim 22 (3/09), at: http://www.daat.ac.il/daat/ktav_et/maamar.asp?ktavet=1\&id=692 (Accessed: 8 December 2018).

\footnotetext{
${ }^{8}$ Schwartz 2014b.
} 